\title{
Astigmatic change following excision of double-headed monocular pterygium (DMP)
}

\author{
Kshama Dwivedi1 ${ }^{1, *}$, S.P Singh ${ }^{2}$ \\ ${ }^{\mathbf{1}}$ Associate Professor, ${ }^{2}$ Professor, Dept. of Ophthalmology, MLN Medical College, Allahabad, Uttar Pradesh, India \\ *Corresponding Author: Kshama Dwivedi \\ Email: drdkshama@gmail.com
}

\begin{abstract}
Introduction: To study the effect of excision of double headed monocular pterygium on astigmatism.

Materials and Methods: 8 Patients of DMP presenting from January 2016 to December 2017 were treated with excision of pterygium followed by conjunctival autograft. Preoperative and postoperative astigmatism was measured by keratometry.

Observation: The change between preoperative and postoperative day 45 astigmatism was found to be extremely significant $(\mathrm{p}=0.0003)$.
\end{abstract}

Conclusion: DMP must be dealt with utmost care, owing to it's higher impact in change of astigmatism.

Keywords: Double headed monocular pterygium, Pterygium induced astigmatism.

\section{Introduction}

Pterygium is elastotic degeneration of subconjunctival tissue leading to wing shaped encroachment of conjunctiva over cornea. Ultraviolet light exposure has been associated to it's increased occurrence. Therefore pterygium is quite common in "pterygium belt region"1 - which extends up to 30 degree of latitude on either side of equator. Commonly it is present on nasal side of cornea, sometimes on both sides of cornea and very rarely on temporal side of cornea. When pterygium is present on both sides of cornea, it is known as double - headed monocular pterygium (DMP). Temporal pterygium is rare and must be differentiated from squamous cell carcinoma. ${ }^{2}$

Pterygium induces astigmatism, that too with the rule astigmatism ${ }^{3}$ (WTR). Actually it induces hemiastigmatism, hence acceptance of cylindrical power is poor and so is the quality of vision. ${ }^{4}$ Since pterygium causes apparent flattening of horizontal meridian, so it induces WTR. Patient with pterygium may have either WTR or ATR, because patient's astigmatism depends upon his pre-existing astigmatism plus pterygium induced astigmatism. ${ }^{3,4}$ Incidence of pterygium can be anything from $10.2 \%$ to $33 \%$ (higher in equatorial areas), but the incidence of double headed pterygium was found to be about $2.5 \% .{ }^{5}$ Common risk factors associated with the development of pterygium are advanced age, male gender, rural areas, dry eyes, outdoor occupation etc. . $^{6-8}$

Lot of work has been done on astigmatism (preoperative and postoperative) in pterygium cases, ${ }^{2,3,9}$ but fewer studies focus biheaded pterygium. ${ }^{10-12}$ Aim of this study was to evaluate the effect of DMP excision on astigmatism.

\section{Materials and Methods}

The study was conducted in the period of January 2016- December 2017.

Patient selection - Any patient with double headed monocular pterygium who presented to hospital for excision, was enrolled in this study. Patients with recurrent pterygium, previous ocular surgeries, corneal opacity and diabetics were excluded from this study. Patients with recurrent pterygium were excluded because astigmatism is likely to be affected by previous surgery. Patients with any other previous ocular surgery and corneal scar were excluded for the same reason. Patients with history of diabetes were excluded as diabetes is expected to affect the corneal healing, and hence the astigmatism. Total 157 eyes with pterygium in 141 patients were operated during this period. Sixteen patients had bilateral pterygium. Nine patients of 141 had uniocular DMP. We lost 1 patient of DMP to follow up. Total 8 patients of DMP completed 6 months follow up and were included in this study.

Age, gender, occupation, pterygium grade and ophthalmological examination findings were noted. Grading of pterygium was done by Maheshwari's classification. ${ }^{4}$ Keratometry was performed on manual keratometer (Bausch and Lomb). In all patients of DMP, preoperative topical steroid fluoromethalone $0.1 \%$ four times a day and topical cyclosporine A $0.05 \%$ twice daily was used for 1 week. All surgeries of DMP were done by a single surgeon (KD). After part preparation topical anesthesia was instilled, as well as local anesthetic was injected subconjunctivally. The nasal and temporal pterygia were marked. The abnormal conjunctiva is cut along it's base, then margins and is reflected on the cornea. Subconjunctival tissue is separated from it's bed by passing a blunt spatula beneath it. It's excision is done based on "Iceberg concept". Now the pterygium tissue is avulsed by a blunt instrument in manner analogous to capsulorrhexis. Cautery was not required in any case. Graft harvested from superior bulbar conjunctiva was divided into two parts, depending upon the sizes of bare areas created, and fixed to recipient sites. My preferred method of fixation is electrocoaptation, though I also use sutures sometimes. Eye was patched for 24 hours. All patients were instructed not to rub their eyes. 
Postoperative topical medications included Tobramycin $0.3 \%+$ Fluoromethalone $0.1 \%$ [four times a day], Cyclosporin $0.05 \%$ [twice daily] and carboxymethylcellulose $0.5 \%$ [three times a day]. Steroid drops were tapered after 2 weeks and stopped after a month, whereas cyclosporine and lubricating drops were continued for 3 months. Minimum follow up required was 6 months, repeat keratometry was performed on postoperative day 7, 30 and 45 .

\section{Observation}

Ninth patient did not turn up for any follow up and hence was excluded from study. Eight patients completed the 6 months follow up protocol and their data was analyzed statistically. The age distribution of these patients was 26-71 years. Mean age was 52 years \pm 15.77 SD. Male: Female ratio was 6:2. 6 patients were outdoor workers whereas 2 were indoor workers. Right eye was involved in 5 patients and left eye in 3 patients. None of the patients had bilateral DMP. Visually significant cataract was present in 3 patients. Grade of temporal pterygium was I in all patients except patient number 9 , whereas nasal pterygium varied between grade I to IV.

Table 1: Patients details of double headed pterygium

\begin{tabular}{|c|c|c|c|c|c|c|c|c|c|c|c|c|c|c|c|}
\hline \multirow[t]{2}{*}{ 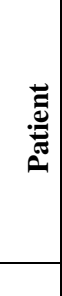 } & \multirow[t]{2}{*}{$\underset{4}{800}$} & \multirow[t]{2}{*}{ 总 } & \multirow[t]{2}{*}{ ס̃ } & \multirow[t]{2}{*}{ 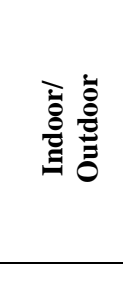 } & \multirow[t]{2}{*}{ 痃 } & \multirow[t]{2}{*}{ 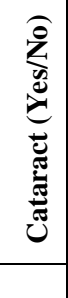 } & \multirow[t]{2}{*}{ 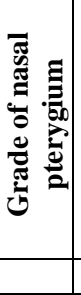 } & \multirow[t]{2}{*}{ 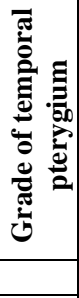 } & \multirow[t]{2}{*}{ 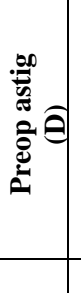 } & \multicolumn{3}{|c|}{ 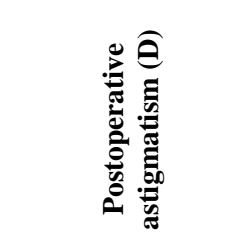 } & \multirow[t]{2}{*}{ 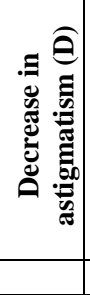 } & \multirow[t]{2}{*}{ 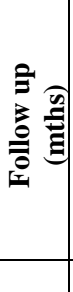 } & \multirow[t]{2}{*}{ 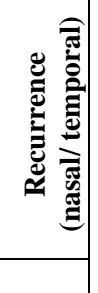 } \\
\hline & & & & & & & & & & D7 & D30 & D45 & & & \\
\hline 1 & 45 & $\mathrm{M}$ & Watchman & Outdoor & $\mathrm{R}$ & $\mathrm{NO}$ & II & $\mathrm{I}$ & 5.0 & 2.0 & 1.5 & 1.5 & 3.50 & 18 & - \\
\hline 2 & 71 & $\mathrm{M}$ & Farmer & Outdoor & $\mathrm{L}$ & YES & III & $\mathrm{I}$ & 7.0 & 4.0 & 2.25 & 1.75 & 5.25 & 6 & - \\
\hline 3 & 66 & $\mathrm{~F}$ & Homemaker & Indoor & $\mathrm{L}$ & $\mathrm{NO}$ & II & $\mathrm{I}$ & 4.0 & 1.5 & 1.0 & 1.0 & 3.00 & 7 & - \\
\hline 4 & 26 & $\mathrm{M}$ & Shopkeeper & Outdoor & $\mathrm{L}$ & $\mathrm{NO}$ & III & $\mathrm{I}$ & 8.0 & 3.5 & 2.5 & 2.25 & 5.75 & 12 & Nasal \\
\hline 5 & 59 & $\mathrm{~F}$ & Sweepress & Outdoor & $\mathrm{R}$ & YES & II & I & 2.5 & 1.0 & 0.5 & 0.5 & 2.00 & 9 & - \\
\hline 6 & 37 & $\mathrm{M}$ & Farmer & Outdoor & $\mathrm{R}$ & $\mathrm{NO}$ & II & $\mathrm{I}$ & 3.25 & 1.25 & 0.75 & 0.5 & 2.25 & 8 & - \\
\hline 7 & 48 & $\mathrm{M}$ & Farmer & Outdoor & $\mathrm{R}$ & $\mathrm{NO}$ & IV & $\mathrm{I}$ & 8.75 & 2.75 & 1.75 & 1.25 & 7.50 & 12 & - \\
\hline 8 & 65 & $\mathrm{M}$ & Retd. clerk & Indoor & $\mathrm{R}$ & YES & II & $\mathrm{I}$ & 4.5 & 1.25 & 0.75 & 0.75 & 3.75 & 9 & - \\
\hline $9^{*}$ & 90 & $\mathrm{~F}$ & Homemaker & Indoor & $\mathrm{L}$ & YES & $\mathrm{I}$ & IV & 12.0 & & & ost to & llow up & & \\
\hline
\end{tabular}

*Ninth patient was lost to follow up and was excluded from analysis

Table 2: Follow up parameters

\begin{tabular}{|l|c|c|c|c|c|}
\hline & $\begin{array}{c}\text { Age } \\
(\mathbf{Y r s})\end{array}$ & $\begin{array}{c}\text { Preop astigmatism } \\
\text { (D) }\end{array}$ & $\begin{array}{c}\text { Postop } \\
\text { astigmatism } \\
\text { (D) }\end{array}$ & $\begin{array}{c}\text { Decrease in } \\
\text { astigmatism (D) }\end{array}$ & $\begin{array}{c}\text { Follow up } \\
\text { (mths) }\end{array}$ \\
\hline Mean & 52 & 5.38 & 1.18 & 4.13 & 10.03 \\
\hline \pm SD & 15.77 & 2.28 & 0.62 & 1.89 & 3.83 \\
\hline & \multicolumn{2}{|r|}{$\mathrm{P}$ value $=0.0003$} & & \\
\hline
\end{tabular}

Preoperative astigmatism varied between 2.5-8.75 $\mathrm{D}$, with mean preoperative astigmatism $5.38 \pm 2.28 \mathrm{SD}$. Postoperative astigmatism showed significant change from preoperative values. Maximum decrease of 7.5 D was seen in patient number 7 (with grade IV+I DMP). Mean postoperative astigmatism at day 7, 30 and 45 were $2.15 \mathrm{D} \pm 1.13 \mathrm{SD}, 1.37 \mathrm{D} \pm 0.74 \mathrm{SD}$ and $1.18 \mathrm{D} \pm$ 0.62 SD. All these patients had WTR. Even in the postoperative period when astigmatism decreased, i.e. the horizontal meridian steepened, it was still flatter than vertical meridian - that is WTR. Mean decrease in astigmatism was $4.13 \mathrm{D} \pm 1.89 \mathrm{SD}$. The change between preoperative and postoperative astigmatism day 45 was statistically highly significant $(\mathrm{p}$ value $=$ 0.0003).

Total follow up period ranged from 6-18 months, with a mean of 10.03 months \pm 3.83 SD. I followed these patients for development of any complications;

like graft oedema, graft retraction, broken sutures, cyst, granuloma or recurrence. Graft oedema was seen in 2 out of 8 patients $(25 \%)$. No other complication was noticed.

\section{Discussion}

Pterygium induces flattening of horizontal meridian due to pooling of the tear film at leading edge of pterygium. ${ }^{13}$ Hence it induces WTR. ${ }^{4}$ Mechanical traction induced by pterygium has little role to play. The astigmatism of patient depends upon his preexisting astigmatism as well as pteygium induced astigmatism (PIA). ${ }^{4}$

PIA depends upon length of pterygium (i.e. grade).$^{4}$ DMP removal creates raw area on both sides of cornea. Using CAG for covering the defects creates 
large superior conjuctival defect which gradually heals with time. I split the graft horizontally ${ }^{11}$ to cover both side bare areas, whereas some authors have split it vertically. ${ }^{12}$ Some authors performed bare sclera on both sides with or without mitomycin C (MMC). ${ }^{14}$ Amniotic membrane is obviously a good alternative if available, although at a cost of slightly increased risk of recurrence. $^{15}$

Objective of this study was to assess keratometric changes following removal of DMP. Literature review did not reveal much of work on it. In an article by Maheshwari (2003), ${ }^{4}$ there was a single case of DMP which was associated with 7D of astigmatism. He has proposed that due to increase in corneal involvement in DMP, the induced astigmatism is higher. Postoperatively the astigmatism reduced to half, although he has not mentioned the grades of pterygium. The author describes his technique of split conjunctival graft $^{11}$ in a separate article, where he mentions the grade of pterygium, but it is not followed by keratometry readings. Similarly in an article by Kodavoor et al, ${ }^{12}$ modified vertically split CAG was used in 87 eyes of 87 patients of double headed pterygium, but astigmatism is not mentioned. Mean keratometric astigmatism in my patients was $5.38 \pm$ $2.28 \mathrm{D}$. Maheshwari et $\mathrm{a}^{16}$ had shown a topographic corneal cylinder of $5.36 \pm 4.97 \mathrm{D}$ in 16 patients of double headed pterygium. This is quite close to my data as measured on keratometry. Postoperatively he has clubbed all grades of pterygium, hence it is not possible to evaluate change of astigmatism of DMP exclusively in his case series. Wu WK et al has described his technique of conjunctival rotation autograft combined with conjunctival autograft. ${ }^{17}$ Postoperatively, there was significant reduction in magnitude of astigmatism $(p=0.016)$ in his case series. My study shows that reduction of astigmatism in case of DHP is extremely significant $(\mathrm{p}$ value $=0.0003$ )

\section{Conclusion}

Number of patients in this study is less, owing to its low incidence. But the amount of postoperative reduction is extremely significant, signifying the fact that DMP induces greater astigmatism. This could be due to the fact that DMP involves greater area of cornea. Hence any amount of DMP must be given utmost importance. E.g., if coexistent with cataract it should be excised first. So that the pterygium induced astigmatism does not affects the IOL power calculation. Minimum interval between excision of DMP and any refractive surgery should be at least 6 weeks. If corneal topography is available, one should monitor the corneal surface to get stabilized.

\section{Acknowledgements}

The author denies any conflicts of interest related to this study. None of the author has any financial interest in the product mentioned.

\section{References}

1. Cameron ME; 1965. Pterygium Throughout the world. Charles C Thomas. Springfield, IL.

2. Ramasamy B, Quah SA, Wishart MS. Temporal pterygium: benign or not? Br J Ophthalmol. 2005;89:1533-1534.

3. Lin A, Stern G. Correlation between pterygium size and induced corneal astigmatism. Cornea. 1998;17:28-30.

4. Maheshwari S. 2003. Effect of pterygium excision on pterygium induced astigmatism. Indian J Ophthalmol. 2003;51:187-88.

5. Dolezalova V. 1977. Is the occurrence of a temporal pterygium so rare? Ophthalmologica. 1977; 174:88-91.

6. Liu L, Wu J, Geng J. Geographical prevalence and risk factors for pterygium: a systematic review and metaanalysis. BMJ Open. 2013;3:e003787.

7. Al-Bdour M, Al- Latayfeh M. Risk factors for pterygium of the eye: a dose response curve. Acta Ophthalmol Scand. 2004;82:64-67.

8. Mackenzie FD, Hirst LW, Battistuta D. Risk analysis in the development of pterygia. Ophthalmol. 1992;99:10561061.

9. Rana Altan- Yaycioglu, Cem Kucukerdonmez, Aylin Karalezli. Astigmatic changes following pterygium removal: Comparison of 5 different methods. Indian $J$ Ophthalmol. 2013;61:104-8.

10. Fulya Duman, Mustafa Kosker. Demographics of patients with double headed pterygium and surgical outcomes. Turk J Ophthalmol. 2015;45:249-253.

11. Maheshwari S. 2005. Split-conjunctival grafts for Double- head pterygium. Indian J Ophthalmol. 2005;53:53-55.

12. Kodavoor SK, Ramamurthy D, Tiwari N N. Double-head pterygium excision with modified vertically splitconjunctival autograft: Six-year long term retrospective analysis. Indian J Ophthalmol. 2017;65:700-4.

13. Yasar T, Ozdemir N, Cinal A. 2003. Effects of fibrovascular traction and pooling of tears on corneal topographic changes induced by pterygium. Eye(Lond). 2003;17(4):492-6.

14. Avisar R, Snir M, Weinberger D. Outcome of double headed pterygium surgery. Cornea. 2003;22:501-3.

15. Lee BH, Lee GJ, Park YJ. Clinical research on surgical treatment for double headed pterygium. J Korean Ophthalmol Soc. 2010;51:642-50.

16. Maheshwari S. Pterygium-induced corneal refractive changes. Indian J Ophthalmol. 2007;55:383-6.

17. Wu WK, Wong VW, Chi SC. Surgical management of double-headed pterygium by using a novel technique: Conjunctival rotational autograft combined with conjunctival autograft. Cornea. 2007;26:1056-9.

How to cite this article: Dwivedi K, Singh S.P. Astigmatic change following excision of doubleheaded monocular pterygium (DMP). Indian $\mathrm{J}$ Clin Exp Ophthalmol. 2018;4(4):515-517. 